\title{
Inventory Reveals Wide Edible Insects' Biodiversity in Selected Territories of South-Kivu Province, Democratic Republic of Congo
}

Jackson Ishara ( $\square$ jackishara17@uea.ac.cd)

Université Evangélique en Afrique

Rodrigue Ayagirwe

Université Evangélique en Afrique

Katcho Karume

Université Evangélique en Afrique

Gustave Mushagalusa

Université Evangélique en Afrique

David Bugeme

Université Catholique de Bukavu

\section{Saliou Niassy}

International Centre of Insect Physiology and Ecology

Patchimaporn Udomkun

International Institute of Tropical Agriculture

John Kinyuru

Jomo Kenyatta University of Agriculture and Technology

\section{Research Article}

Keywords: Edible insects, Entomophagy, Seasonal availability, Host plants, Harvesting techniques, Processing methods

Posted Date: July 29th, 2021

DOl: https://doi.org/10.21203/rs.3.rs-744787/v1

License: (c) (1) This work is licensed under a Creative Commons Attribution 4.0 International License.

Read Full License 
Inventory reveals wide edible insects' biodiversity in selected Territories of South-Kivu

\section{Jackson Ishara ${ }^{1,2 *}$, Rodrigue Ayagirwe ${ }^{3}$, Katcho Karume ${ }^{4}$, Gustave Mushagalusa ${ }^{4}$, David} Bugeme $^{5}$, Saliou Niassy ${ }^{6}$, Patchimaporn Udomkun ${ }^{7}$, John Kinyuru ${ }^{2}$

${ }^{1}$ Department of Food Science and Technology, Université Evangélique en Afrique, P.O. Box 3323-Bukavu, D.R. Congo

${ }^{2}$ Department of Food Science and Technology, Jomo Kenyatta University of Agriculture and Technology, P.O. Box 62000-00200, Nairobi, Kenya

${ }^{3}$ Department of Animal Sciences, Université Evangélique en Afrique, P.O Box: 3323, Bukavu, D.R. Congo

${ }^{4}$ Department of Crop Sciences, Université Evangélique en Afrique, P.O Box: 3323, Bukavu, D.R. Congo

${ }^{5}$ Crop Production and Protection Unit, Catholic University of Bukavu, D.R. Congo

${ }^{6}$ International Centre of Insect Physiology and Ecology (icipe), P.O. Box 30772-00100, Nairobi, Kenya

${ }^{7}$ International Institute of Tropical Agriculture (IITA), Bujumbura, Burundi

*Corresponding author: jackishara17@uea.ac.cd 


\section{Abstract}

39 In response to growing food demand, edible insects are seen as a potential source to alleviate 40 food insecurity. With its wide edible insects' biodiversity, the Democratic Republic of Congo 41 is one of the most important biodiversity hotspots in Africa. This study aimed at giving a first 42 insight on inventory showing diversity, perception, consumption, availability, host plants, 43 harvesting techniques and processing techniques of edible insects in South-Kivu, DRC. It 44 recorded twenty-three edible insects belonging to nine families and five orders, some of which are consumed in the larval, adult, egg and pupa stages. Rhyncophorus phoenicis, Alphitobius diaperinus, Macrotermes subhylanus and Acheta domesticus were the most preferred edible insects in Fizi Territory, Ruspolia differens and Apis melifera larvae in Kabare Territory, Imbrasia oyemensis, Imbrasia epimethea, Rhynchophorus ferrugineus and Rhyncophorus phoenicis in Mwenga Territory, Ruspolia differens, Macrotermes subhylanus, Gryllotalpa africana, Nsike, Nomadacris septemfasciata and Apis melifera larvae in Walungu Territory. $R$. differens, I. oyemensis, A. melifera larvae, G. africana and Nsike were preferred for their taste. A. domesticus, A. diaperinus and A. melifera larvae were abundant throughout the year, while others were only available for 9 months or less per year. Numerous plants have been recorded as their hosts, including plants used for food and income. Harvesting strategies and period, processing methods and preservation techniques depend on insect species, local knowledge and practices. These findings suggest similar and thoroughly studies on entomophagy across the country, while encouraging the rearing of edible insects to address the high existing demand and environmental need.

Keywords: Edible insects; Entomophagy; Seasonal availability; Host plants; Harvesting techniques; Processing methods 


\section{Introduction}

The world's population is expected to reach 9.8 billion by 2050 and 11.2 billion by 2100 (UN, 2019), meaning that demand for food and feed production will increase (Godfray, et al., 2010). In this regard, edible insects have been highlighted as potential in tackling this issue, in addition to their environmental and economic benefits ( Premalatha et al., 2011; Halloran et al., 2015; Kinyuru et al., 2015). With their protein content and other nutrients similar to and in some cases higher than that of fish and soy (Sánchez-Muros et al., 2014), edible insects production have been advocated as an alternative to conventional meat production (Van Huis, 2013; Payne et al., 2015; Kinyuru et al., 2018).

Edible insects are traditionally consumed in many parts of the world (Rumpold \& Schlüter, 2013), as at least 2 billion people eat them on a regular basis (Van Huis \& Oonincx, 2017), not only because of their nutritional value but for their taste as well (Kou \& Adámková, 2016; Mishyna \& Chen, 2020). Moreover, food and nutrient insecurity remains one of the most fundamental challenges in the Democratic Republic of Congo (DRC), especially in places with less favorable climatic conditions (Doocy et al., 2018). Thus, disadvantaged communities desperately depend on forest products, including edible insects, as they are among the most abundant forest resources (Kim et al., 2017; Vliet et al., 2019). Hence, they play an incredible role throughout the year, especially during the rainy season, depending on the geographical location of different cultures (Bomolo et al., 2017).

Among more than 2000 species of edible insects reported worldwide (Jongema, 2017), the most consumed are beetles (Coleoptera, 31\%), caterpillars (Lepidoptera, 18\%), and bees, wasps, and ants (Hymenoptera, 14\%). This is followed by grasshoppers, locusts and crickets (Orthoptera, 13\%), cicadas, leafhoppers, plant hoppers, scale insects and true bugs (Hemiptera, 10\%), termites (Isoptera, 3\%), dragonflies (Odonata, 3\%), flies (Diptera, 2\%) and $5 \%$ other orders (Van Huis, 2013). Additionally, the availability of some edible insects depends on the geographical distribution of their host plants and seasonality (Chakravorty et al., 2013), and correlate with their harvesting period (Takeda \& Sato, 1993). In turn, successful harvesting of edible insects depends on insect habits and ecological factors (Kelemu et al., 2015), as they are harvested at different growth stages, including the larval (bees, beetles, butterflies, and ants) and adult (beetles, ants, grasshoppers) stages. For some species, harvesting is easy at night or early in the morning when they are inactive and, therefore, could not fly (Kinyuru et al., 2010). Harvesting techniques of edible insects are a mixture of observations, hand-picking, tracings, sign interpretations, and trapping strategies (Hanboonsong et al., 2013), and vary from one insect to another. Among them, the most commonly used are hand-picking commonly used for 
106 crickets, Rhinocerus beetle, African palm weevil, and caterpillars, while light trapping is the 107 most used to harvest termites, green grasshoppers, house cricket, and mole cricket (Meutchieye 108 et al., 2016; Ebenebe et al., 2017).

109 Studies on edible insects have been conducted in Africa, America, Asia, Europe and Australia

110 to assess key variables in entomophagy perception and practices (Van Huis, 2013; Hartmann 111 et al., 2015; Kelemu et al., 2015; Kinyuru et al., 2015; Cicatiello et al., 2016; Laureati et al., 112 2016; Raheem et al., 2018; Schlup \& Brunner, 2018; Wilkinson et al., 2018; Woolf et al., 113 2019). Despite the wide diversity of edible insects in the DRC, there are few studies on edible 114 insects' inventory except the study conducted on ecological diversity of edible insects and their 115 potential contribution to household food security in Haut-Katanga Province (Bomolo et al., 116 2017) and on entomophagy in the area surrounding LuiKotale, Salonga National Park (Payne 117 et al., 2016). However, to the best of our knowledge, in South Kivu, there is little-to-no research 118 on the biodiversity, perception, consumption, availability, host plants, harvesting techniques 119 and processing techniques of edible insects. Due to differences in ecology, culture and dietary 120 habits from other studied regions, the results of other research cannot be extrapolated to South121 Kivu consumers. Therefore, there is need for more detailed study in this regard. 


\section{Material and methods}

\subsection{Ethics statement}

142 All experimental protocols as well as methods were approved and carried out in accordance

143 with relevant guidelines and regulations from the Interdisciplinary Centre for Ethical Research

144 (CIRE) established by the Evangelical University in Africa, Bukavu, D.R. Congo, with 145 reference (UEA/SGAC/KM 132/2016). Informed consent form describing the aim of the study 146 was signed by all subjects after translation into local languages.

\section{$147 \quad$ 2.2. Study area}

148 The survey and direct observation were carried out in four selected Territories (Fizi, Kabare, 149 Mwenga and Walungu) of South-Kivu Province, D.R. Congo where data on diversity, host 150 plants, seasonal availability, harvesting techniques and traditional processing, consumption, 151 preference of edible insects were collected. These Territories (Figure 1) were purposively 152 selected for their familiarity with entomophagy as it is traditionally practiced by local 153 communities. These selected Territories are in different agroecological conditions with 154 different cultures influencing edible insects' availability and consumption as well.

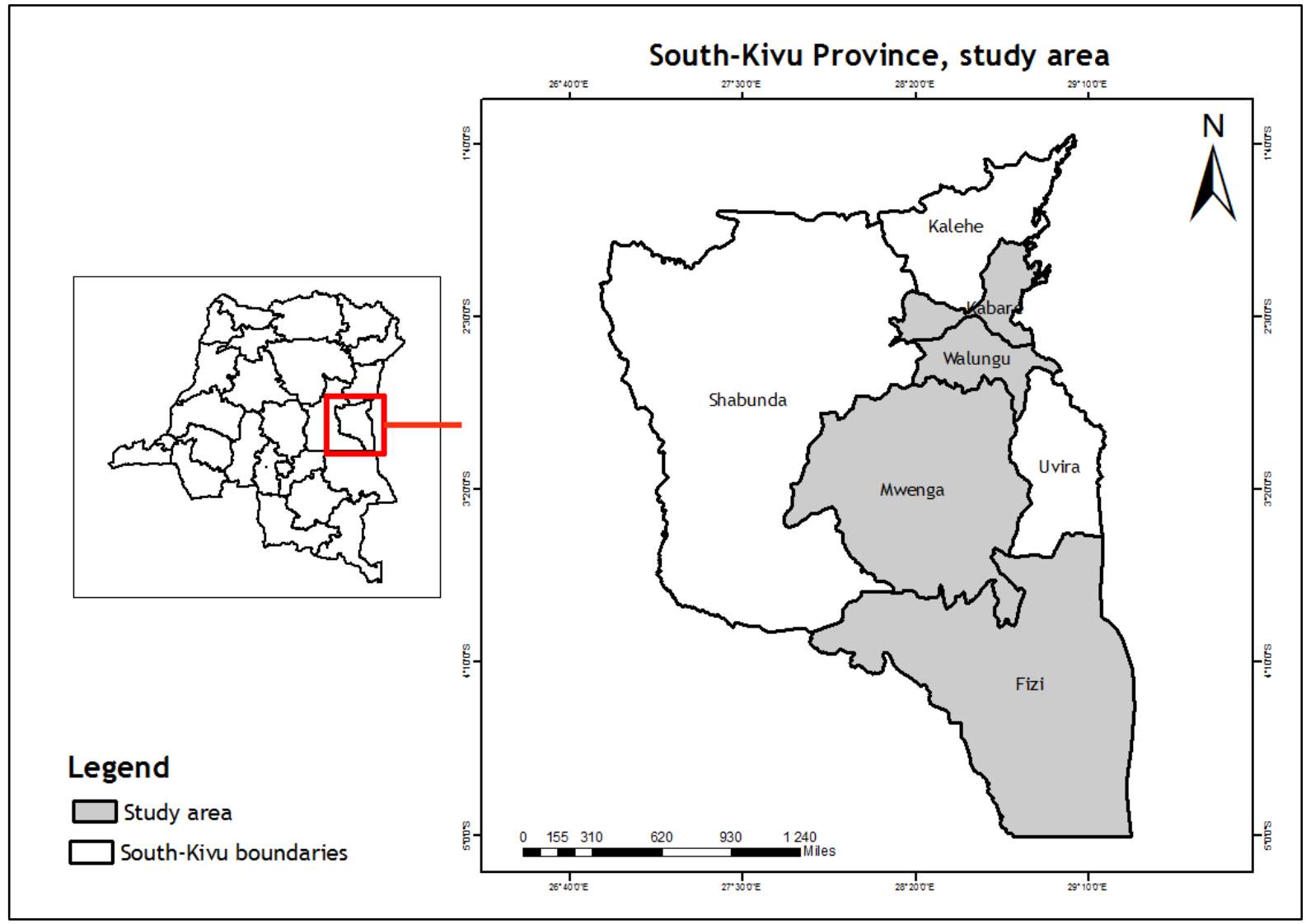

Figure 1. Map showing South-Kivu Province and the study Territories 
Table 1. Agro-ecological conditions of the study area (CAID, 2021)

\begin{tabular}{|c|c|c|c|c|}
\hline \multirow[t]{2}{*}{ Characteristics } & \multicolumn{4}{|c|}{ Territory } \\
\hline & Fizi & Walungu & Kabare & Mwenga \\
\hline Latitude (South) & $\begin{array}{l}3^{\circ} 30 \text { to } 4^{\circ} \\
51^{\prime} 32\end{array}$ & $2^{\circ} 38^{\prime}$ & $2^{\circ} 30^{\prime}$ & $3^{\circ}$ to $4^{\circ}$ \\
\hline Longitude (East) & $\begin{array}{l}27^{\circ} 45 \text { to } 29^{\circ} \\
14^{\prime} 10\end{array}$ & $28^{\circ} 40^{\prime}$ & $28^{\circ} 30^{\prime}$ & $28^{\circ} 25^{\prime} 29^{\prime \prime}$ \\
\hline Area $\left(\mathrm{km}^{2}\right)$ & 15,789 & 1,800 & 1,960 & 11,172 \\
\hline Altitude (m) & 750 to 1,700 & 1,000 to 2000 & 1,420 to 3,200 & 670 to 1,800 \\
\hline Climate type & $\begin{array}{l}\text { Humid wet and } \\
\text { dry tropical }\end{array}$ & $\begin{array}{l}\text { Humid wet } \\
\text { tropical }\end{array}$ & $\begin{array}{l}\text { Humid wet } \\
\text { tropical }\end{array}$ & Equatorial \\
\hline Dominant soil unity & $\begin{array}{l}\text { Acrisols and } \\
\text { Cambisols }\end{array}$ & $\begin{array}{l}\text { Ferralsols, } \\
\text { Cambisols } \\
\text { and Nitisols }\end{array}$ & $\begin{array}{l}\text { Ferralsols and } \\
\text { Nitisols }\end{array}$ & $\begin{array}{l}\text { Acrisols and } \\
\text { Cambisols }\end{array}$ \\
\hline Mean $\mathrm{T}^{\circ} \mathrm{C}$ & $23.54{ }^{\circ} \mathrm{C}$ & $17-20^{\circ} \mathrm{C}$ & $22.6^{\circ} \mathrm{C}$ & $21-37^{\circ} \mathrm{C}$ \\
\hline Mean Annual P(mm) & 1,704 & 900 to 1,500 & 1,572 & 1,650 \\
\hline $\begin{array}{l}\text { Estimated Population } \\
\text { (2019) }\end{array}$ & $1,093,926$ & $1,509,175$ & 868,616 & 843,636 \\
\hline $\begin{array}{l}\text { Density of population } \\
\left(\mathrm{hab} \cdot \mathrm{km}^{-2}\right)\end{array}$ & 69.3 & 838.4 & 443.6 & 75.5 \\
\hline AEZ* & $\begin{array}{l}\text { Low and high } \\
\text { altitude }\end{array}$ & $\begin{array}{l}\text { Medium to } \\
\text { high altitude }\end{array}$ & $\begin{array}{l}\text { Medium to high } \\
\text { altitude }\end{array}$ & $\begin{array}{l}\text { Low and high } \\
\text { altitude }\end{array}$ \\
\hline
\end{tabular}

Agro-ecological conditions of the study area are presented in the Table 1. The Territory of Fizi is located between $3^{\circ} 30$ and $4^{\circ} 5132$ latitude (South), and $27^{\circ} 45$ and $29^{\circ} 1410$ longitude (East).

164 Its elevation is subdivided into four zones including the coastline $(\sim 750 \mathrm{~m})$, the inland low valley $(\sim 1,000 \mathrm{~m})$, a highland $(\sim 1,300 \mathrm{~m})$, and the very highland (locally called haut plateau with $1,700 \mathrm{~m}$ ). The climate in Fizi is highly affected by the elevation. The rainfalls are unevenly distributed according to the month and the climatic subdivision. The north dominated with coastline and inland low valley is characterized with humid tropical climate (of Aw3 type according to Köppen-Geiger classification), the greatest rainfall amounts are recorded in March and November, while the smallest amounts in February and September. The south part has dry

171 humid tropical climate. Available climate data mentioned an average annual rainfall of $\sim 1,704$ $172 \mathrm{~mm}$, the mean temperature $\sim 23.54{ }^{\circ} \mathrm{C}$ (with the highest observed in April with $\sim 25.6{ }^{\circ} \mathrm{C}$ and 173 the lowest $\sim 21.3{ }^{\circ} \mathrm{C}$ in September). The territory is dominated by forest, comprising two forest 
174

175

176

177

178

179

180

181

182

183

184

185

186

187

188

189

190

191

192

193

194

195

196

197

198

199

200

201

202

203

204

reserves and a nature reserve. Acrisols and Cambisols are the dominant soil unities according to the WRB classification.

The Kabare Territory is located between $2^{\circ} 30^{\prime}$ of South latitude and $28^{\circ} 30^{\prime}$ of East longitude. Its altitude varies from $\sim 1,420$ to 3,200 $\mathrm{m}$ and the Territory occupies an area of $\sim 1690 \mathrm{~km}^{2}$ with an estimated population of $\sim 868,616$ which makes it among the most populated in the SouthKivu province. The Territory is located in the medium to high altitude AEZ. Available meteorogical data mentioned an annual rainfall average of $\sim 1,572 \mathrm{~mm}$, and temperature of $\sim 22.6{ }^{\circ} \mathrm{C}$. Most of Kabare is savanna with natural vegetation consisting of wild grasses.

The Territory of Mwenga is located in the middle of the province and is the only Territory surrounded with the other without any country or province borders. It is located between $28^{\circ} 25^{\prime} 29^{\prime \prime}$ East longitude and $30^{\circ} 02,16^{\prime} 05^{\prime \prime}$ South latitude. Its altitude varies between 1,500 and $1,800 \mathrm{~m}$ in the northeast. In the center and the South, it is more or less $670 \mathrm{~m}$. In the East, it is more or less $200 \mathrm{~m}$ and in the West more or less $670 \mathrm{~m}$. It has a humid tropical climate with two seasons: the dry season from June to September and the rainy season from September to May. The temperature varies between 21 and $37^{\circ} \mathrm{C}$ in most of the Territory and is low in the Itombwe area because of the high altitude which goes up to over $2000 \mathrm{~m}$. Rainfall reaches $2,000 \mathrm{~mm}$ to $3,000 \mathrm{~mm}$ per year. The vegetation is mainly dense forest and savanna. The forest is home to the Itombwe Nature Reserve (RNI). Relief is dominated with the Itombwe mount uplands and the alluvial valley of the Elila watershed. Soils dominated with clayey (Humic Cambisols) and sandy soil (Acrisols) types.

The Territory of Walungu is located between $2^{\circ} 38^{\prime}$ of South latitude and $28^{\circ} 40^{\prime}$ of East longitude. Its altitude varies between $1,000 \mathrm{~m}$ and $2,000 \mathrm{~m}$ with a cold tropical climate of low altitude. There are two seasons, the dry season (June to August) and the rainy season from September to March. Available station data presented an annual average of $\sim 17-20^{\circ} \mathrm{C}$, and 900 and $1500 \mathrm{~mm}$ for temperature and rainfall respectively. The vegetation is mainly consisted of grassland, a few forest reserves of Mugaba and Mushwere and woodlands scattered throughout the Territory.

\subsection{Sampling and selection of respondents}

A total of 520 respondents, about 130 respondents in each Territory, were interviewed, with priority given to people familiar with entomophagy based on the main objectives set. The respondents therefore included adults, women and men over 18 years old and from all social 
classes. A structured oral interview was used on an individual basis to ensure better information and to minimize external influences on the respondent's side.

\subsection{Sources of data collected}

Primary data were obtained from the field survey using three techniques namely questionnaire administration, direct observations and insect collection.

\subsubsection{Questionnaire administration}

211 Structured questionnaires were used to obtain information on edible insects in all selected Territories of South-Kivu. The questionnaire was divided into seven sections. In the first section, information about the respondents was collected. Section two contained open-ended questions related to commonly consumed edible insects, focusing on local name and stage of consumption. The third section contained questions about consumer preferences and preference factors. The fourth section included questions related to seasonal availability. In the fifth section, questions about host plants and signs of presence were asked, followed by personal observations. The sixth section dealt with harvesting techniques and timing. The last section dealt with processing methods and preservation techniques. The enumerators translated the questions into the local dialect to enhance understanding of respondents. Pictures and real samples of various edible insects identified from literature were also used to help respondents identify the insects being mentioned. To enhance the depth of information solicited, enumerators probed further for clarification on some responses.

\subsubsection{Direct observations}

225 In the field, direct observations of relevant information related to insects and their habitats in the different territories were recorded. Pictures were taken to verify and support the results of the responses obtained from the interviewees. In addition, the researcher had the opportunity to observe how some edible insects were prepared and consumed.

\subsubsection{Collection and taxonomic identification of insect samples}

230 Samples of edible insects were collected as part of the survey and the collected insects were preserved in $70 \%$ alcohol and taken to the laboratory at Lwiro Research Center for identification. A mixture of primary data and taxonomic characters was used to identify and classify the various species of edible insects in the different territories. The taxonomic characters were derived mainly from archival sources and published literature.

\subsection{Data analysis}

Data were analysed using R 4.0.0. and Microsoft Excel 16.16.27. The completed questionnaires were cleaned and information verified. Based on the nature of the research questions descriptive and exploratory approaches were used to delineate and describe the existence and 
use of edible insects in various Territories. Descriptive statistics and Pearson's chi-square correlation tests $(5 \%)$ were applied to analyze the collected data where applicable.

\section{Results and discussion}

\subsection{Commonly consumed edible insects in selected Territories of South-Kivu}

243 A total of twenty-three edible insects including Macrotermes subhylanus, Acheta domesticus, 244 Rhyncophorus phoenicis, Alphitobius diaperinus, Ruspolia differens, Gryllotalpa africana, Apis melifera larvae, Nomadacris septemfasciata, Locusta migratoria, Rhynchophorus ferrugineus, Imbrasia oyemensis, Imbrasia epimethea, Oryctes monoceros, Cirina forda, Nsike, Kigelegele, Kansenda, Bangwangwa, Maguina, Mingungu, Ngohangoha, Bikolongo and Bachache were inventoried as source of food in the Territories of Fizi, Kabare, Mwenga and Walungu Territories (Table 2, Figure 2). They all belong to nine families including Termitidae, Gryllidae, Curculionidae, Tenebrionidae, Acrididae, Gryllotalpidae, Apidae, Saturniidae and Scarabaeidae and five orders including Isoptera, Orthoptera, Coleoptera, Hymenoptera and Lepidoptera.

From all the inventoried edible insects, four (M. subhylanus, A. domesticus, $R$. phoenicis and A. diaperinus) were found in Fizi, eleven (M. subhylanus, A. domesticus, $R$. differens, $G$. africana, A. melifera larvae, $N$. septemfasciata, L. migratoria, R. ferrugineus, I. oyemensis, I. epimethea and Nsike) in Kabare, seventeen (M. subhylanus, A. domesticus, R. phoenicis, A. diaperinus, R. ferrugineus, I. oyemensis, I. epimethea, O. monoceros, C. forda, Kigelegele, Kansenda, Bangwangwa, Maguina, Mingungu, Ngohangoha, Bikolongo and Bachache) in Mwenga, and eight (M. subhylanus, A. domesticus, R. differens, G. africana, A. melifera larvae, N. septemfasciata, L. migratoria, and Nsike) in Walungu.

The M. subhylanus and A. domesticus were found to be used as source of food in whole study area, namely Fizi, Kabare, Mwenga and Walungu Territories, while $R$. phoenicis and $A$. diaperinus are consumed only in Fizi and Mwenga. In Kabare and Walungu Territories $R$. differens, G. africana, A. melifera larvae, N. septemfasciata, L. migratoria and Nsike are used as source of food. Moreover, R. ferrugineus, I. oyemensis and I. epimethea are used as source of food in both Kabare and Mwenga. However, O. monoceros, C. forda, Kigelegele, Kansenda, Bangwangwa, Maguina, Mingungu, Ngohangoha, Bikolongo and Bachache are only used as source of food only in Mwenga Territory.

As for the stage of consumption, some edible insect species were consumed at the larval stage including $R$. phoenicis, A. diaperinus, A. melifera larvae, $R$. ferrugineus, I. oyemensis, $I$. epimethea, O. monoceros, C. forda, Maguina, Mingungu, Ngohangoha, Bikolongo and

272 Bachache, and others at the adult stage (M. subhylanus, A. domesticus, R. differens, G. 
273 africana, Nsike, Kigelegele, Kansenda, and Bangwangwa). Unlike the others edible insects, 274 the $A$. melifera is even consumed as egg and pupa. 
Table 2. Commonly consumed edible insects in selected Territories of South-Kivu

\begin{tabular}{|c|c|c|c|c|c|c|c|c|c|}
\hline \multirow{2}{*}{$\begin{array}{l}\text { Common } \\
\text { name }\end{array}$} & \multirow[t]{2}{*}{ Scientific name } & \multirow[t]{2}{*}{ Family } & \multirow[t]{2}{*}{ Order } & \multicolumn{4}{|c|}{ Territory } & \multirow[t]{2}{*}{ Local name } & \multirow{2}{*}{$\begin{array}{l}\text { Stage of } \\
\text { consumption }\end{array}$} \\
\hline & & & & Fizi & Kabare & Mwenga & Walungu & & \\
\hline Termite & $\begin{array}{l}\text { Macrotermes } \\
\text { subhylanus }\end{array}$ & Termitidae & Isoptera & + & + & + & + & Lolongue/Bushungwe & Winged adult \\
\hline $\begin{array}{l}\text { House } \\
\text { cricket }\end{array}$ & Acheta domesticus & Gryllidae & Orthoptera & + & + & + & + & $\begin{array}{l}\text { Makelele/Njanjala } \\
\text { /hungwe/Ntoro }\end{array}$ & Adult \\
\hline Palm weevil & $\begin{array}{l}\text { Rhyncophorus } \\
\text { phoenicis }\end{array}$ & Curculionidae & Coleoptera & + & - & + & - & Ebungu/Sololo/Mpose & Larvae \\
\hline Beetle & $\begin{array}{l}\text { Oryctes } \\
\text { rhinoceros }\end{array}$ & Scarabaeidae & Coleoptera & + & - & + & - & Sungunya/Njukisha & $\begin{array}{l}\text { Larvae and } \\
\text { adult }\end{array}$ \\
\hline Grasshopper & Ruspolia differens & Acrididae & Orthoptera & - & + & - & + & Minunu & Adult \\
\hline Mole cricket & $\begin{array}{l}\text { Gryllotalpa } \\
\text { Africana }\end{array}$ & Gryllotalpidae & Orthoptera & - & + & - & + & Nkwananzi & Adult \\
\hline Honey bee & Apis melifera & Apidae & Hymenoptera & - & + & - & + & Magusha/Manyagu & $\begin{array}{l}\text { Egg, larva and } \\
\text { pupa }\end{array}$ \\
\hline Red locust & $\begin{array}{l}\text { Nomadacris } \\
\text { septemfasciata }\end{array}$ & Acrididae & Orthoptera & - & + & - & + & Mundurha & Adult \\
\hline $\begin{array}{l}\text { Migratory } \\
\text { locust }\end{array}$ & $\begin{array}{l}\text { Locusta } \\
\text { migratoria }\end{array}$ & Acrididae & Orthoptera & - & + & - & + & Tondé & Adult \\
\hline $\begin{array}{l}\text { Red palm } \\
\text { weevil }\end{array}$ & $\begin{array}{l}\text { Rhynchophorus } \\
\text { ferrugineus }\end{array}$ & Curculionidae & Coleoptera & - & + & + & - & Bivumbe & Larvae \\
\hline Caterpillar & $\begin{array}{l}\text { Imbrasia } \\
\text { oyemensis }\end{array}$ & Saturniidae & Lepidoptera & - & + & + & - & Milanga & Larvae \\
\hline Caterpillar & $\begin{array}{l}\text { Imbrasia } \\
\text { epimethea }\end{array}$ & Saturniidae & Lepidoptera & - & + & + & - & Taku/Tukumombo & Larvae \\
\hline $\begin{array}{l}\text { Rhinoceros } \\
\text { beetle }\end{array}$ & $\begin{array}{l}\text { Oryctes } \\
\text { monoceros }\end{array}$ & Scarabaeidae & Coleoptera & - & - & + & - & Batumbu & Larvae \\
\hline Misigi & Cirina forda & Saturniidae & Lepidoptera & - & - & + & - & Misigi & Larvae \\
\hline Nsike & NI & NI & $\mathrm{NI}$ & - & + & - & + & Nsike & Adult \\
\hline Kigelegele & NI & NI & NI & - & - & + & - & Kigelegele & Adult \\
\hline Kansenda & NI & NI & NI & - & - & + & - & Kansenda & Adult \\
\hline Bangwangwa & NI & NI & NI & - & - & + & - & Bangwangwa & Adult \\
\hline
\end{tabular}




\begin{tabular}{|c|c|c|c|c|c|c|c|c|c|}
\hline Maguina & NI & NI & NI & - & - & + & - & Maguina & Larvae \\
\hline Mingungu & NI & NI & NI & - & - & + & - & Mingungu & Larvae \\
\hline Bikolongo & NI & NI & NI & - & - & + & - & Bikolongo & Larvae \\
\hline
\end{tabular}

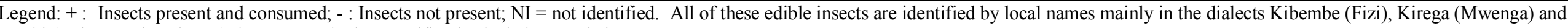
Mashi (Kabare and Walungu) that are attached to specific physical characteristics or uses. 


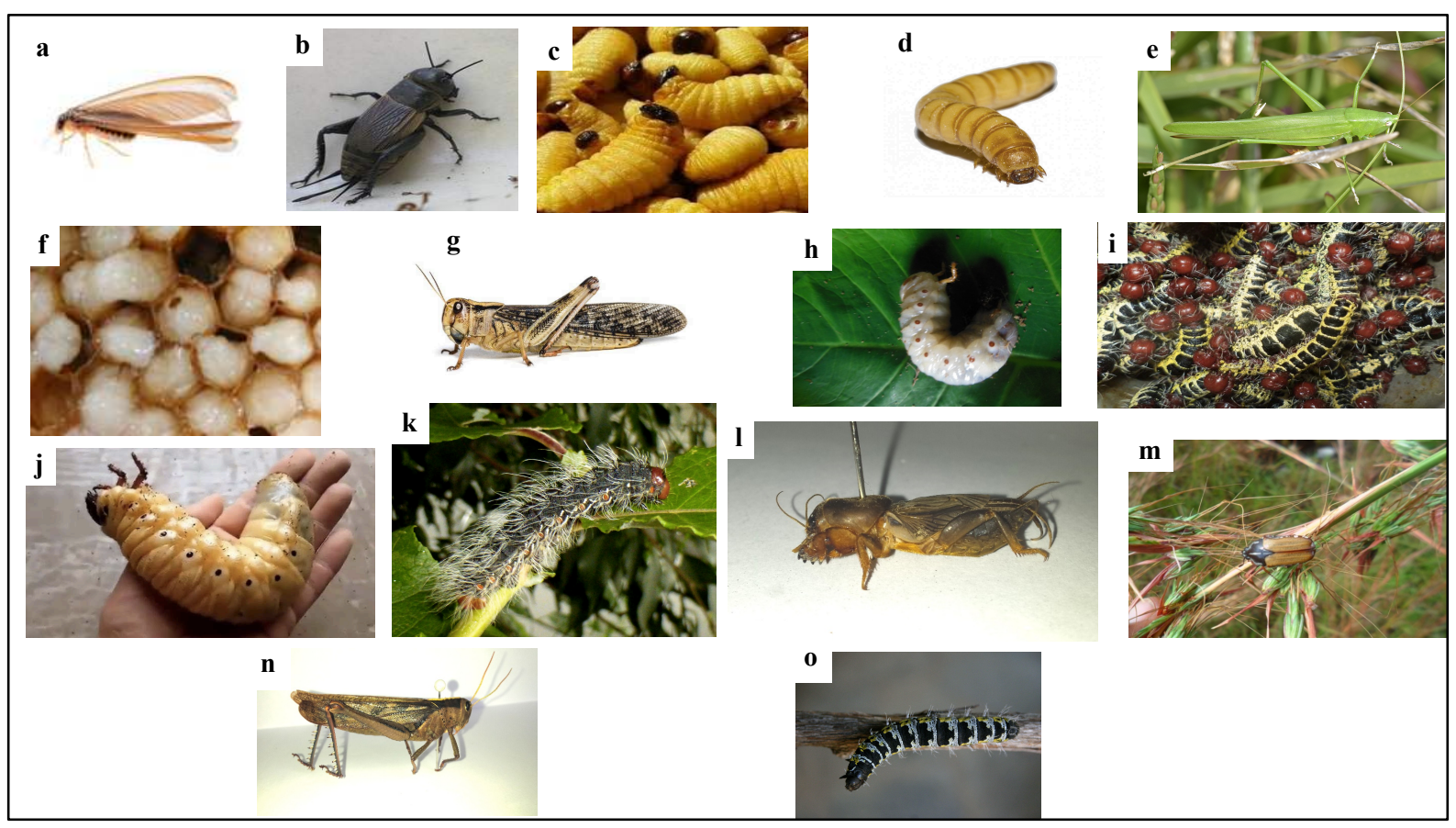

Figure 2. a. Macrotermes subhylanus (Termite); b. Acheta domesticus (House cricket); c. Rhyncophorus phoenicis larvae (Palm weevil larvae); d. Alphitobius diaperinus larvae (Beetle); e. Ruspolia differens (Grasshopper); f. Apis melifera larvae (Honey bee); g. Locusta migratoria (Migratory locust); h. Rhynchophorus ferrugineus larvae (Red palm weevil); i. Imbrasia oyemensis (Caterpillar); j. Oryctes monoceros larvae (Rhinoceros beetle); k. Imbrasia epimethea (Caterpillar); l. Gryllotalpa Africana (Mole cricket ); m. Nsike ; n. Nomadacris septemfasciata (Red locust ); o. Cirina forda (Misigi).

The wide biodiversity of edible insect species revealed in South Kivu clearly depicts the importance of entomophagy in the region. Our findings are largely in agreement with that of Bomolo et al. (2017) who reported a list of eleven edible insect species belonging to four families in Haut-Katanga Province confirming that the Democratic Republic of Congo has a high diversity of edible insects making it one of the most important biodiversity hotspots in Africa. This biodiversity in terms of edible insects in DRC is also confirmed by Raheem et al. (2018) who reported on traditional consumption and rearing of edible insects in Africa, Asia and Europe. Similarly, Kelemu et al. (2015) noted that most edible insects consumed in DRC belong to these orders.

This diversity could be associated to the richness of the natural environment conditions (Twine et al., 2003) in each Territory as most of the edible insects are gathered from the wild (Levang et al., 2015). In addition, the geographic distribution of host plants influences the availability of certain edible insects. A low number of caterpillar species has been attributed to marked deforestation, forest degradation and pollution (Ramos-elorduy, 2006; Schabel, 2006). This situation is likely to worsen, with the growing human populations and declining forest base 
301 (Hoare, 2007). Previous studies reported that edible insects consumption and preference are 302 also influenced by their availability and cultures (Hanboonsong et al., 2013; Raubenheimer \& 303 Rothman, 2013).

304 Findings from this study line with Raheem et al. (2019) who reported that more than a thousand 305 insect species are worldwide consumed at some stage of their life cycle. In addition, 306 Lepidoptera consumed as caterpillars and Hymenoptera are mostly eaten in their larval or pupal

307

308

309

310

311

312

313

314

315

316

317

318

319

320

321

322

323

324

325

326

327 stages like the $A$. melifera mentioned from the survey to be consumed as egg and pupa. Adults as well as larvae of Coleoptera are consumed, while the Orthoptera, Isoptera and Hemiptera orders are mostly consumed as mature adults (Kelemu et al., 2015). Moreover, Kulma et al. (2020) who investigated the effect of developmental stage on the nutritional value of edible insects (Blaberus craniifer and Zophobas morio) reported that there were no significant variation in basic nutrient content, in protein quality expressed as the essential amino acid index. In contrast, they reported a significant difference in protein digestibility, fat content and lipid quality.

\subsection{Consumer preference for edible insects}

The inventoried edible insects were appreciated differently (Figure 3). In Fizi the most preferred edible insects were the $R$. phoenicis (41\%), A. diaperinus (26\%), M. subhylanus (20\%), and A. domesticus (13\%), while in Kabare the most preferred were R. differens (55\%) and $A$. melifera larvae (45\%). Furthermore, I. oyemensis (65\%), I. epimethea (20\%), $R$. ferrugineus (11\%) and $R$. phoenicis (4\%) were the most preferred in Mwenga, while, $R$. differens (39\%), M. subhylanus (22\%), G. africana (21\%), Nsike (10\%), N. septemfasciata (7\%) and $A$. melifera larvae (1\%) were most preferred in Walungu. Some edible insects were preferred in more than one Territory, such as M. subhylanus (Fizi and Walungu), R. phoenicis (Fizi and Mwenga), R. differens and A. melifera larvae (Kabare and Walungu). 


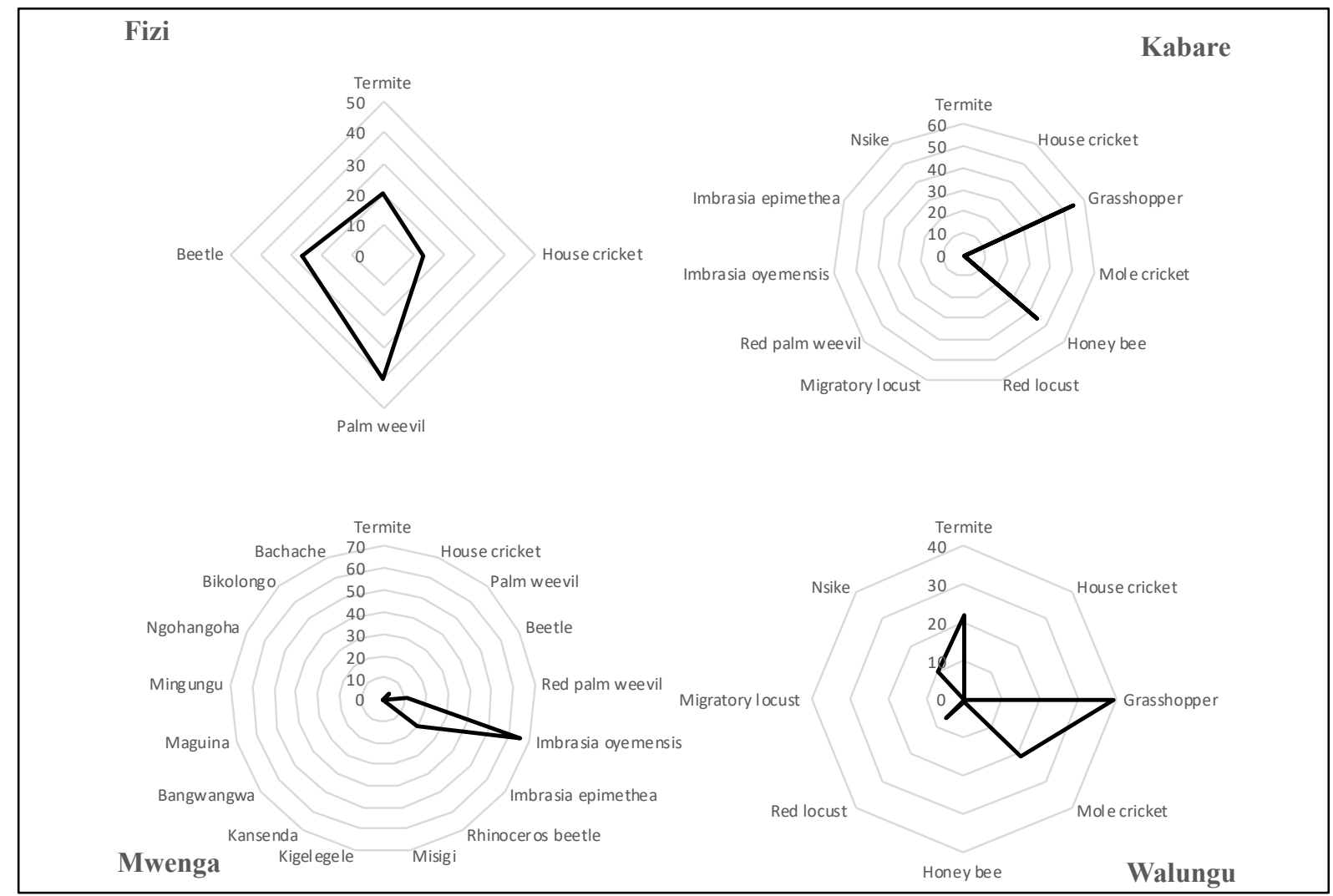

329 Figure 3. Most preferred edible insects in each Territory $(n=130)$. This is the number of times

330 each edible insect is preferred. The preference is expressed in percentage.

331 This preference have been reported to be linked to availability (Van Huis, 2013; Obopile \& 332 Seeletso, 2013), ethnicity/cultures (Riggi et al., 2016), palatability (Chakravorty et al., 2013)

333 and seasonality (Kinyuru et al., 2013) as some species are more prevalent and familiar in some

334 Territories than others. In addition, indigenous knowledge and processing can also influence 335 the preference of edible insect species (Obopile \& Seeletso, 2013). Familiarity appears to be 336 the key driving force, allowing most respondents to react positively to all edible species in 337 terms of their willingness to eat them and thus contribute to addressing food and nutrition 338 insecurity and related issues.

339 Bomolo et al. (2017) revealed that caterpillar consumption is a common practice among ethnic 340 populations in D.R. Congo. This is not the case for the population of Walungu, Kabare and 341 Fizi, although it is the most appreciated edible insects in Mwenga. In Katanga the Bemba and 342 Lamba tribes have a long history of caterpillar consumption since the 18th and 19th centuries 343 (Malaisse \& Latham, 2014), while the other tribes (Musanga, Tetela, Mongo, Baluba, Rund, 344 Bacongo, Katshokwe, Emba, Songe, Ndembo, Kaminungu, Kalwena, Kete, Basankusu, 345 Kanyoka, Sanga, Mbote, Yombe, etc.) appear to lack a strong history of caterpillar 346 consumption. In addition, some of these tribes are reluctant to engage in entomophagy, 
specifically to consume caterpillars due to their religious beliefs (Meyer-rochow, 2009).

348 Studies have shown that education would play a crucial role in increasing the positive attitude 349 towards edible insects among consumers (Looy \& Wood, 2006; Van Huis, 2013).

\section{$350 \quad 3.7 . \quad$ Preference for edible insects}

351 The plotted data (Figure 4) give an idea of the factors of appreciation for the most preferred 352 inventoried edible insects ( $G$. africana, $R$. differens, A. melifera larvae, Nsike, $N$.

353

354

355

356

357

358

359

360 septemfasciata and I. oyemensis) represented in two Territories $(\mathrm{n}=260)$. Respondents rated them according to taste, size, shape, nutritional value and color. Most of these insects were valued for their taste especially $R$. differens (33\%), I. oyemensis (32\%), A. melifera larvae (17\%), G. africana (3\%), and Nsike (2\%) with the exception of $N$. septemfasciata which was valued for its size (3\%) and shape (0.4\%). As for size, R. differens (5\%), G. africana (4\%) and N. septemfasciata (3\%) were the most valued. Most of these edible insects were not valued for their nutritional value or color except for $A$. melifera larvae $(0.4 \%)$ and $I$. oyemensis $(1 \%)$ for nutritional value and $R$. differens (3\%) and Nsike (1\%) for color.

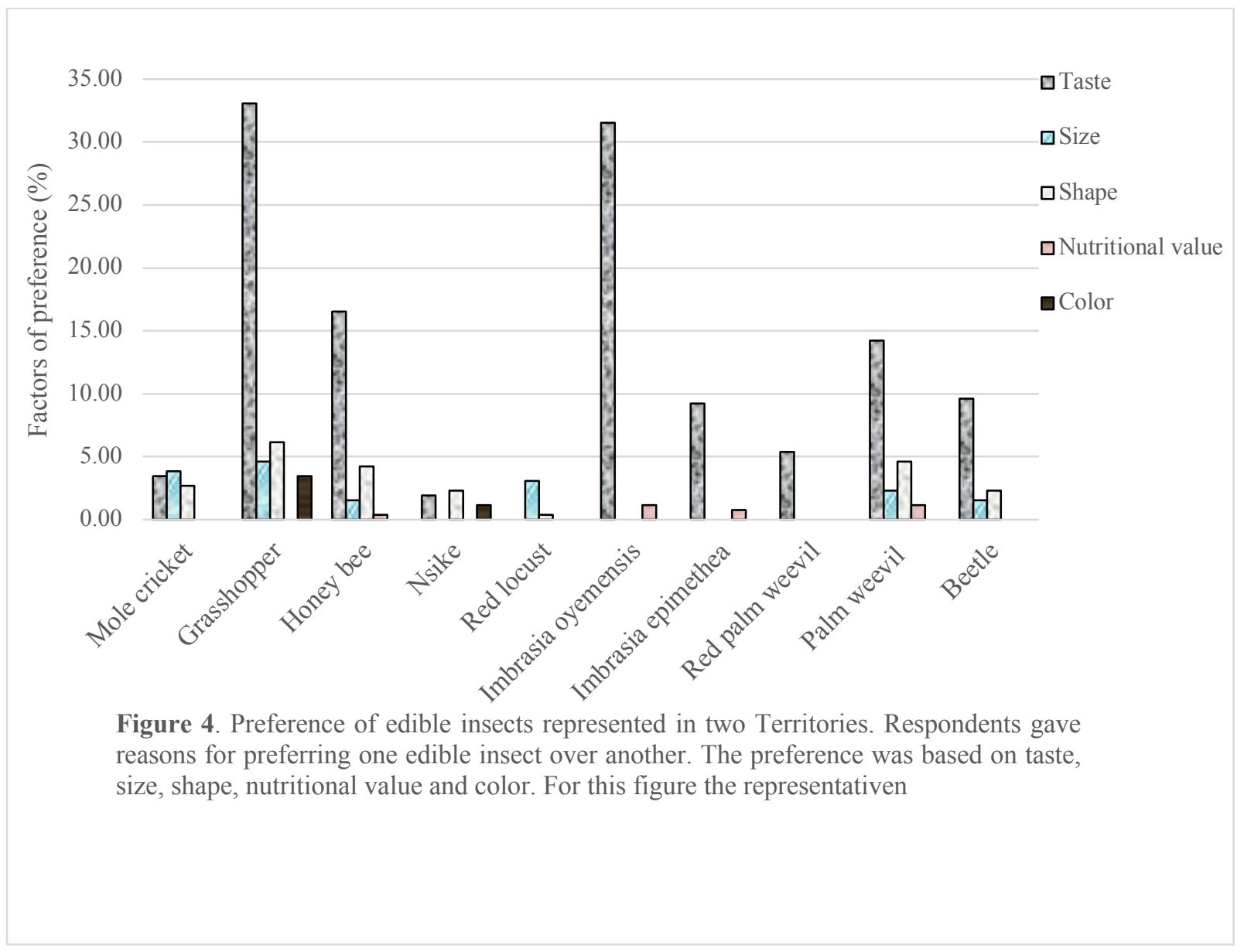

Considering $M$. subhylanus and A. domesticus represented in all Territories $(n=520)$. Irrespective of Territories, their appreciation depended only on their taste, size and 
shape (Figure 5). More appreciation was based on the taste with $8 \%$ and $3 \%$ against $2 \%$ and $1 \%$ for the size for M. subhylanus and A. domesticus respectively, only M. subhylanus was appreciated for its shape (1\%).

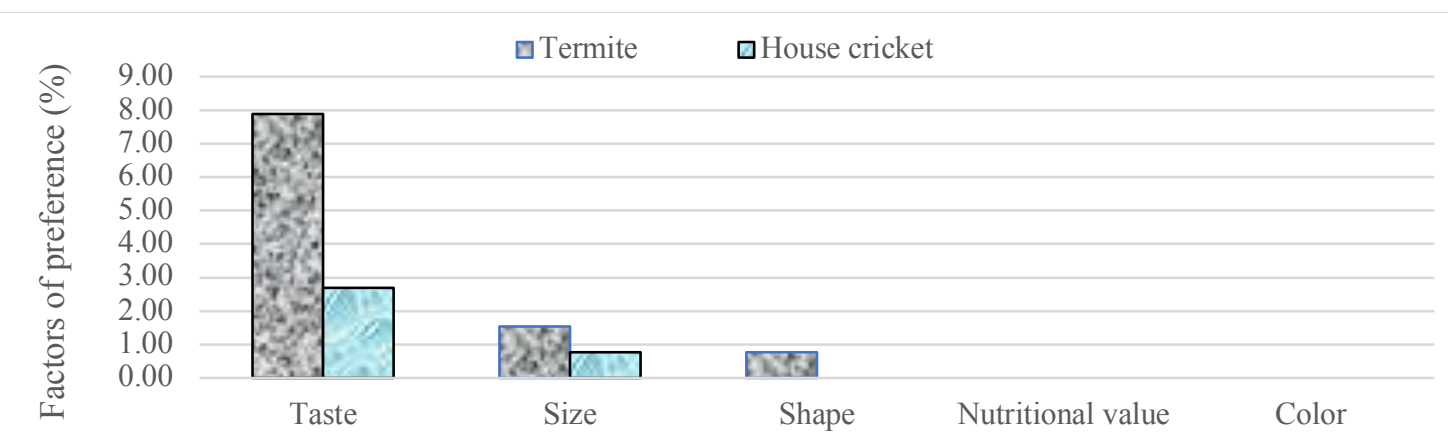

Figure 5. Preference of Termites and House crickets in the study area. Respondents gave reasons for preferring one edible insect over another. The preference was based on taste, size, shape, nutritional value and color. For this figure the representativen

367

368

369

370

371

372

373

374

375

376

377

378

379

380

381

382

383

384

385

386

387

388

Entomophagy habits differ from country to country and culture to culture, as do preference factors. Insect consumption depends not only on sensory characteristics (Van Huis, 2013) and nutritional value ( Obopile \& Seeletso, 2013; Kinyuru et al., 2018), but also on customs, ethnic preferences, prohibitions (Van Huis \& Oonincx, 2017), and medicinal properties (Musundire et al., 2014). Insects were once associated with filth, fear of contamination and disease, as well as psychological and biased thinking about taste, smell, and color (Deroy et al., 2015), with a sense of disgust that entomophagy was motivated by starvation and is merely a survival mechanism (Van Huis, 2013). This is far from the truth, as insects are not inferior to other protein sources, such as fish, chicken, and beef. Although it will take a bit more motivation to reverse this mentality (Pliner \& Salvy, 2006). It is possible to explore edible insects for consumption and increase the possibility of replacing animal products with insects, given that there is evidence that they are clean, tasty, and nutritious (Gahukar, 2011).

In addition, insects have too many ecological advantages over other animal protein sources (Rumpold \& Schlüter, 2013). Some studies in European countries such as the Netherlands (Lensvelt \& Steenbekkers, 2014) on the acceptance of entomophagy have shown that people who have eaten insects in the past show significantly more positive attitudes towards entomophagy than people who have not, and are more likely to eat them again. Therefore, it seems important to encourage people to take the "first step" and familiarize them with insect consumption. Therefore, consumer "education" about entomophagy should be practiced in its broadest sense (Lensvelt \& Steenbekkers, 2014). 


\subsection{Seasonal availability of various inventoried edible insects}

390 Regardless of Territory, three groups of edible insects, mainly A. domesticus, A. diaperinus 391 and A. melifera larvae, are abundant throughout the year (Table 3). Nomadacris septemfasciata 392 is also available throughout the year, but abundant only during 5 months and less abundant 393 from from February to August. Gryllotalpa africana and R. ferrugineus, on the other hand, 394 were abundant throughout the rainy season and are less abundant in the dry season. G. africana 395 and $R$. ferrugineus are not abundant, respectively in August and June. Both species are all 396 unavailable in July. Elsewhere, M. subhylanus, R. phoenicis and R. differens are available half 397 the year (6 months). However, M. subhylanus and $R$. differens were less available for 3 months 398 of the year while $R$. phoenicis are only available for one month of the year. Other groups such 399 as Oryctes monoceros, Cirina forda, Ngohangoha, I. oyemensis, Nsike, Mingungu, Bikolongo 400 and Bachache were abundant for only 3 to 4 months of the year. In contrast, I. epimethea, 401 Maguina, Kigelegele, Kansenda and Bangwangwa were the most available and abundant for 402 only one to two months of the year.

403 
Table 3. Seasonal availability of various inventoried edible insects

\begin{tabular}{|c|c|c|c|c|c|c|c|c|c|c|c|c|c|c|}
\hline \multirow[t]{2}{*}{ Insect species } & \multicolumn{5}{|c|}{ Rain season } & \multicolumn{3}{|c|}{ Dry season } & \multicolumn{4}{|c|}{ Rain season } & \multirow[b]{2}{*}{ TMA } & \multirow[b]{2}{*}{ TLA } \\
\hline & Jan & Feb & Mar & Apr & May & Jun & Jul & Aug & Sep & Oct & Nov & Dec & & \\
\hline Termite & + & + & + & + & - & 0 & 0 & 0 & - & - & + & + & 6 & 3 \\
\hline House cricket & + & + & + & + & + & + & + & + & + & + & + & + & 12 & 0 \\
\hline Palm weevil & 0 & 0 & 0 & + & + & + & + & - & 0 & 0 & + & + & 6 & 1 \\
\hline Beetle & + & + & + & + & + & + & + & + & + & + & + & + & 12 & 0 \\
\hline Grasshopper & + & - & - & + & + & 0 & 0 & 0 & - & + & + & + & 6 & 3 \\
\hline Mole cricket & + & + & + & + & + & 0 & 0 & - & + & + & + & + & 9 & 1 \\
\hline Honey bee & + & + & + & + & + & + & + & + & + & + & + & + & 12 & 0 \\
\hline Red locust & + & - & - & - & - & - & - & - & + & + & + & + & 5 & 7 \\
\hline Migratory locust & - & - & 0 & 0 & 0 & 0 & 0 & 0 & 0 & 0 & + & + & 2 & 2 \\
\hline Red palm weevil & + & + & + & + & + & - & 0 & 0 & + & + & + & + & 9 & 1 \\
\hline Imbrasia oyemensis & 0 & + & + & + & - & 0 & 0 & 0 & 0 & 0 & 0 & 0 & 3 & 1 \\
\hline Imbrasia epimethea & 0 & + & + & - & 0 & 0 & 0 & 0 & 0 & 0 & 0 & 0 & 2 & 1 \\
\hline Rhinoceros beetle & + & + & + & - & - & 0 & 0 & 0 & 0 & 0 & 0 & + & 4 & 2 \\
\hline Misigi & + & + & + & - & 0 & 0 & 0 & 0 & 0 & 0 & 0 & + & 4 & 1 \\
\hline Nsike & 0 & 0 & 0 & + & + & + & - & - & 0 & 0 & 0 & 0 & 3 & 2 \\
\hline Kigelegele & 0 & + & - & 0 & 0 & 0 & 0 & 0 & 0 & 0 & 0 & 0 & 1 & 1 \\
\hline Kansenda & 0 & 0 & + & - & 0 & 0 & 0 & 0 & 0 & 0 & 0 & 0 & 1 & 1 \\
\hline Bangwangwa & - & 0 & 0 & 0 & 0 & 0 & 0 & 0 & 0 & 0 & 0 & + & 1 & 1 \\
\hline Maguina & 0 & + & + & - & 0 & 0 & 0 & 0 & 0 & 0 & 0 & 0 & 2 & 1 \\
\hline Mingungu & 0 & 0 & + & + & + & - & 0 & 0 & 0 & 0 & 0 & 0 & 3 & 1 \\
\hline Ngohangoha & 0 & 0 & 0 & 0 & 0 & 0 & + & + & + & + & - & 0 & 4 & 1 \\
\hline Bikolongo & 0 & 0 & + & + & + & - & 0 & 0 & 0 & 0 & 0 & 0 & 3 & 1 \\
\hline Bachache & 0 & + & + & + & - & 0 & 0 & 0 & 0 & 0 & 0 & 0 & 3 & 1 \\
\hline
\end{tabular}

Legend: + : month of availability ; - : month of less availability ; 0 : month of none availability; TMA: Total month of availability; TLA: Total month of less availability. 
406

407

408

409

410

411

412

413

414

415

416

417

418

419

420

421

422

423

424

425

426

427

428

429

430

431

432

433

434

435

436

437

438

Availability is an important factor in the consumption of edible insects (Chakravorty et al., 2013). Our results corroborate with those of Ebenebe et al. (2017) who pointed out that most of the harvesting is done during the rainy season in Nigeria especially for winged termites, cricket, caterpillars, A. domesticus, G. africana, and greenish beetle. Smith \& Paucar (2000) suggest that vibrations caused by rain and the sound of thunder would trigger their emergence. Chakravorty et al. (2013) also confirmed that the availability of edible insects is seasonal, stating that peak numbers of edible beetles occur from June to September, before decreasing in winter and early spring. They also reported that Odonata and Orthoptera were most abundant in September and October (late summer).

Insects of the order Hemiptera and Hymenoptera are less abundant in the period from November to February (winter), while others such as bugs and ants are available throughout the year. This would be attributed to seasonal changes in various regions of the world. In the Central African Republic, the average consumption of caterpillars increases as a consequence of their greater abundance during the rainy season (Van Huis, 2013), as seasonal availability and consumption of edible insects are correlated (Takeda \& Sato, 1993). In contrast to our findings, all developmental stages of $R$. differens can be found throughout the year in nonswarming population but at low densities during dry seasons population and high densities during rainy seasons (Opoke et al., 2019).

\subsection{Host plants for various inventoried edible insects}

Some edible insects such as M. subhylanus, A. domesticus, G. africana, A. melifera larvae, Kigelegele, Kansenda and Bangwangwa do not necessarily have host plants, but others such as $R$. phoenicis, A. diaperinus, $R$. differens, $N$. septemfasciata, L. migratoria, $R$. ferrugineus, $I$. oyemensis, I. epimethea, O. monoceros, C. forda and Nsike require host plants to serve either for habitat or source of food (Table 4). Edible insects such as N. septemfasciata and L. migratoria are dangerous as they use maize (Zea mays), rice (Oryza sativa), soy bean (Glycine max), sugar cane (Saccharum officinarum), ground nuts (Arachis hypogaea) and sweet potato (Ipomoea batatas) crops as host plants, while the latter are also sources of staple foods for humans. On the other hand, others species $R$. phoenicis, A. diaperinus, $R$. ferrugineus and $O$. monoceros were hosted on Raffia palm, Cocos nucifera, Elaeis guineensis, and Mangifera spp trees which are not only source of food for humans and a source of income for many people. Their signs of presence differ from one to another. The presence of $R$. phoenicis, A. diaperinus, $R$. ferrugineus and O. monoceros is noticed by cracking noises in palm trunks, odor and indication of their activities at the hole of entrance. Furthermore, caterpillar smells and typical 
439 bird songs were signs of presence for I. oyemensis and I. epimethea. Moreover, G. africana, N. 440 septemfasciata, L. migratoria and C. forda are noticed by whistling and canals in the wet 441 ground.

442

443

444

445

446

447

448

449

450

451

452 
Table 4. Host plants of various consumed edible insects

\begin{tabular}{|c|c|c|c|}
\hline \multirow[b]{2}{*}{ Insect species } & \multicolumn{2}{|r|}{ Host plants } & \multirow[b]{2}{*}{ Signs of presence } \\
\hline & Common name & Scientific name & \\
\hline Termite & NA & NA & NA \\
\hline House cricket & NA & NA & NA \\
\hline Palm weevil & $\begin{array}{l}\text { Palm, Coconut and African oil } \\
\text { palm }\end{array}$ & Raffia palm, Cocos nucifera and Elaeis guineensis & $\begin{array}{l}\text { Cracking noises in palm } \\
\text { trunks and odor }\end{array}$ \\
\hline Beetle & Palm, Yellow Flame and Mango & $\begin{array}{l}\text { Raffia palm, Peltophorum pterocarpum and } \\
\text { Mangifera spp }\end{array}$ & $\begin{array}{l}\text { Indication of its activity at } \\
\text { the hole of entrance and } \\
\text { cracking noises in palm. }\end{array}$ \\
\hline Grasshopper & $\begin{array}{l}\text { Grass, Guinea grass and giant rat's } \\
\text { tail grass }\end{array}$ & $\begin{array}{l}\text { Digitaria sp, Panicum maximum, and Sporobolis } \\
\text { pyramidalis }\end{array}$ & NA \\
\hline Mole cricket & NA & NA & $\begin{array}{l}\text { Whistling and canals in the } \\
\text { wet ground }\end{array}$ \\
\hline Honey bee & NA & NA & NA \\
\hline Red locust & $\begin{array}{l}\text { Maize, Rice, Soyabean, Sugarcane, } \\
\text { Groundnut and Sweet potato }\end{array}$ & $\begin{array}{l}\text { Zea mays, Oryza sativa, Glycine max, Saccharum } \\
\text { officinarum, Arachis hypogaea and Ipomoea batatas }\end{array}$ & Whistling \\
\hline Migratory locust & $\begin{array}{l}\text { Maize, Rice, Soyabean, Sugarcane, } \\
\text { Groundnut and Sweet potato }\end{array}$ & $\begin{array}{l}\text { Zea mays, Oryza sativa, Glycine max, Saccharum } \\
\text { officinarum, Arachis hypogaea and Ipomoea batatas }\end{array}$ & Whistling \\
\hline Red palm weevil & $\begin{array}{l}\text { Coconut, African oil palm and } \\
\text { sugarcane }\end{array}$ & $\begin{array}{l}\text { Cocos nucifera, Elaeis guineensis and Saccharum } \\
\text { officinarum, }\end{array}$ & $\begin{array}{l}\text { Indication of its activity at } \\
\text { the hole of entrance, odor } \\
\text { and cracking noises in palm. }\end{array}$ \\
\hline $\begin{array}{l}\text { Imbrasia } \\
\text { oyemensis }\end{array}$ & Red mangrove & Rhizophora mangle & $\begin{array}{l}\text { Caterpillar smells and typical } \\
\text { bird songs }\end{array}$ \\
\hline $\begin{array}{l}\text { Imbrasia } \\
\text { epimethea }\end{array}$ & $\begin{array}{l}\text { Red mangrove and African } \\
\text { blackwood }\end{array}$ & Rhizophora mangle and Erythrophleum africanum & $\begin{array}{l}\text { Caterpillar smells and typical } \\
\text { bird songs }\end{array}$ \\
\hline Rhinoceros beetle & Coconut and African oil palm & Cocos nucifera and Elaeis guineensis & $\begin{array}{l}\text { Indication of its activity at } \\
\text { the hole of entrance and } \\
\text { Cracking noises in palm. }\end{array}$ \\
\hline Misigi & $\begin{array}{l}\text { Red mangrove and African } \\
\text { blackwood }\end{array}$ & Rhizophora mangle and Erythrophleum africanum & $\begin{array}{l}\text { Whistling } \quad \text { Continued } \\
\end{array}$ \\
\hline
\end{tabular}


Table 4. Continued

\begin{tabular}{|c|c|c|c|}
\hline \multirow[b]{2}{*}{ Insect species } & \multicolumn{2}{|r|}{ Host plants } & \multirow[b]{2}{*}{ Signs of presence } \\
\hline & Common name & Scientific name & \\
\hline Nsike & $\begin{array}{l}\text { Jaragua grass, Weeping lovegrass } \\
\text { and Giant rat's tail grass }\end{array}$ & $\begin{array}{l}\text { Hyparrhenia rufa, Eragostis curvula and Sporobolis } \\
\text { pyramidalis }\end{array}$ & NA \\
\hline Kigelegele & NA & NA & NA \\
\hline Kansenda & NA & NA & NA \\
\hline Bangwangwa & NA & NA & NA \\
\hline Maguina & NYD & NYD & NYD \\
\hline Mingungu & NYD & NYD & NYD \\
\hline Ngohangoha & NYD & NYD & NYD \\
\hline Bikolongo & NYD & NYD & NYD \\
\hline Bachache & NYD & NYD & NYD \\
\hline
\end{tabular}

Legend: NA= Not Applicable; NYD = Not Yet Determined. 
Ebenebe et al. (2017) highlighted that certain edible insects are associated with the following host plants: cricket-yam; yam beetle-yam; African palm weevil-raffia palm; Rhinoceros beetleraffia palm, oil palm, coconut tree; butterfly-iroko (Chlorophora excelsa), locust bean seed (Parkia biglobosa), flambouyant tree (Delonixregia), croton (Croton tiglium) and ngwu tree; grasshopper and honey bee-Jatropha gossyplifolia, Citrus sinensis, Morinda lucida, Psidium guajava and Sarcocepha laifolius. According to Ngute et al. (2020), five of the eleven caterpillar species studied in central Cameroon were reported to have only one host plant, while others had more than one. They identified eighteen plants of which eleven are restricted to natural forest habitats, including Entandrophragma cylindricum and Baillonella toxisperma. Although many of the identified caterpillar host plants are generally in the wild, a few are domesticated and grown in home gardens and agroforestry systems such as Mangifera indica and Dacryodes edulis, or are in the process of domestication such as Ricinodendron heudelotii, B. toxisperma and E. cylindricum (Ngute et al., 2020). Also, it should be noted that most of the hosts are plants used as a source of food and revenue; for example, the plant B. toxisperma is a class A timber species, which produces fruits with a highly valued and edible oil is extracted (Meunier et al., 2015).

It has been reported that out of 21,252 observations, $R$. differens were observed 20,915 (98\%) times on grasses and sedges, with a total of 19 grass species (Poaceae) and two sedge species (Cyperaceae). Among the grasses the dominant species were P. maximum, B. ruziziensis, $C$. gayana, H. rufa, Cynodon dactylon, Sporobolus pyramidalis and P. purpureum (Opoke et al., 2019). When reared in the laboratory $R$. differens accept artificial food, leaves, flowers, and grains of many grasses, including cultivated cereals (Malinga et al., 2018; Valtonen et al., 2018). At this point, our findings line with those of Meutchieye et al. (2016), who observed that the cracking noises in the palm trunks three to four weeks after the final collection of palm wine, the yellow of the internal raffia bamboo, caterpillar odors and typical bird songs and whistling are the signs indicating the presence of $R$. phoenicis, caterpillars, $R$. differens and field crickets.

\subsection{Harvesting and processing techniques of edible insects}

In this study, we found that harvesting time and techniques vary according to local knowledge, practices, and the insect species (Table 5). Three harvesting techniques were identified, including trapping, hand picking and collection. M. subhylanus (during and after the first rains) and $R$. differens (during the swarming season) are trapped with light near a container, once attracted by light, they fall inside before being collected then dewinged. In addition, $R$. differens 
497 picking at any time. Furthermore, R. phoenicis, A. diaperinus, G. africana, A. melifera larvae,

498 N. septemfasciata, L. migratoria, R. ferrugineus, I. oyemensis, I. epimethea, O. monoceros, $C$. 499 forda, Nsike, Maguina, Mingungu, Ngohangoha, Bikolongo and Bachache are hand-picked.

500 As for the harvesting period, some edible insects are collected only in the morning or evening,

501 while others are collected any time, but preferably in the evening or morning. $R$. differens are

502 light trapped soon after the dark. Like N. septemfasciata, L. migratoria and Nsike, R. differens

503 are also hand-picked in the morning before the sun rises when they are not yet able to fly. The

504 harvest decreases with the intensity of the sun. On the other hand, A. melifera larvae and $G$.

505 africana are respectively collected at night and in the evening preferably. Rhyncophorus

506 phoenicis, A. diaperinus, R. ferrugineus, I. oyemensis, I. epimethea, O. monoceros, C. forda,

507 Maguina, Mingungu, Ngohangoha, Bikolongo and Bachache are collected Any time during the

508 day, but preferably in the morning and evening hours.

509 Processing methods and preservation techniques vary according to the type of edible insect and 510 the purpose, whether it is for direct consumption or for preservation. Generally, they are all 511 dried or dry-fried for preservation except for the honeybee (Table 5). Most of the edible insects 512 with wings such as M. subhylanus, A. domesticus, R. differens, G. africana, N. septemfasciata, 513 L. migratoria and Nsike are dewinged before being roasted, dry-fried, fried or boiled for $G$. 514 africana. M. subhylanus are also eaten raw. Rhyncophorus phoenicis, A. diaperinus, $R$.

515 ferrugineus, I. oyemensis, I. epimethea, O. monoceros, C. forda, Maguina, Ngohangoha and 516 Bachache are gut removed, washed, boiled, fried or roasted, and sometimes prepared in stews. 517 A. melifera larvae are only boiled while Kigelegele, Bangwangwa, Mingungu and Bikolongo 518 are boiled and roasted.

519

520

521

522

523 
Table 5. Harvesting and processing techniques for various consumed edible insects in selected Territories

\begin{tabular}{|c|c|c|c|c|}
\hline $\begin{array}{l}\text { Insect } \\
\text { species }\end{array}$ & Harvesting techniques & Harvesting period & Processing methods & $\begin{array}{l}\text { Preservation } \\
\text { techniques }\end{array}$ \\
\hline Termite & $\begin{array}{l}\text { Trap termites with light near a container, } \\
\text { termites attracted by light fall inside before } \\
\text { being collected and have their wing } \\
\text { removed }\end{array}$ & During and after the first rains & $\begin{array}{l}\text { Dewinged, roasted or dry-fried; } \\
\text { also eaten raw }\end{array}$ & Drying \\
\hline $\begin{array}{l}\text { House } \\
\text { cricket }\end{array}$ & Trapping and hand picking & Any time & Dewinged, roasted or dry-fried & Drying \\
\hline Palm weevil & $\begin{array}{l}\text { Hand picking after signs of their presence } \\
\text { are detected. }\end{array}$ & Any time based on signs & $\begin{array}{l}\text { Gut removed, boiled, fried or } \\
\text { roasted, sometimes prepared in } \\
\text { stews }\end{array}$ & Drying \\
\hline Beetle & $\begin{array}{l}\text { Hand picking after signs of their presence } \\
\text { are detected. }\end{array}$ & Any time based on signs & $\begin{array}{l}\text { Washed, boiled, fried or roasted, } \\
\text { sometimes prepared in stews }\end{array}$ & Drying \\
\hline Grasshopper & $\begin{array}{l}\text { During the swarming season light trapping } \\
\text { technique is used to attract grasshopper in } \\
\text { addition to hand picking on host plants }\end{array}$ & $\begin{array}{l}\text { Soon after the dark for light } \\
\text { trapping and morning before the } \\
\text { sun rises when they could not fly } \\
\text { for hand picking }\end{array}$ & Dewinged, roasted or dry-fried & $\begin{array}{l}\text { Dry-fried during the } \\
\text { swarming season }\end{array}$ \\
\hline Mole cricket & Hand picking & $\begin{array}{l}\text { In the evening following their } \\
\text { small holes }\end{array}$ & $\begin{array}{l}\text { Dewinged, roasted or dry-fried } \\
\text { and boilled }\end{array}$ & Drying \\
\hline Honey bee & $\begin{array}{l}\text { Collecting honeycomb from the hive } \\
\text { following with honey extraction }\end{array}$ & At night preferably & Boiled & None \\
\hline Red locust & Hand picking on host plants & Morning time & Dewinged, roasted or dry-fried & Drying \\
\hline $\begin{array}{l}\text { Migratory } \\
\text { locust }\end{array}$ & Hand picking on host plants & Morning time & Dewinged, roasted or dry-fried & $\begin{array}{l}\text { Drying when it's } \\
\text { enough }\end{array}$ \\
\hline $\begin{array}{l}\text { Red palm } \\
\text { weevil }\end{array}$ & $\begin{array}{l}\text { Hand picking after signs of their presence } \\
\text { are detected. }\end{array}$ & Any time based on signs & $\begin{array}{l}\text { Washed, boiled, fried or roasted, } \\
\text { sometimes prepared in stews }\end{array}$ & Drying \\
\hline \multirow[t]{2}{*}{ Caterpillar } & $\begin{array}{l}\text { Hand picking: caterpillar directly picked } \\
\text { after signs of their presence are detected. }\end{array}$ & $\begin{array}{l}\text { Any time during the day preferably } \\
\text { morning and evening hours }\end{array}$ & $\begin{array}{l}\text { Boiled, fried or roasted, } \\
\text { sometimes prepared in stews }\end{array}$ & Drying \\
\hline & & & & Continued \\
\hline
\end{tabular}


Table 5. Continued

\begin{tabular}{|c|c|c|c|c|}
\hline $\begin{array}{l}\text { Insect } \\
\text { species }\end{array}$ & Harvesting techniques & Harvesting period & Processing methods & Preservation techniques \\
\hline $\begin{array}{l}\text { Rhinoceros } \\
\text { beetle }\end{array}$ & $\begin{array}{l}\text { Hand picking after signs of their presence } \\
\text { are detected. }\end{array}$ & $\begin{array}{l}\text { Any time during the day preferably } \\
\text { morning and evening hours }\end{array}$ & $\begin{array}{l}\text { Boiled, fried or roasted, } \\
\text { sometimes prepared in stews }\end{array}$ & Drying \\
\hline Misigi & $\begin{array}{l}\text { Hand picking after signs of their presence } \\
\text { are detected. }\end{array}$ & $\begin{array}{l}\text { Any time during the day preferably } \\
\text { morning and evening hours }\end{array}$ & $\begin{array}{l}\text { Boiled, fried or roasted, } \\
\text { sometimes prepared in stews }\end{array}$ & Drying \\
\hline Nsike & Hand picking on host plants & $\begin{array}{l}\text { During the sunny period, they are } \\
\text { easy to identify and hand picking } \\
\text { on the top of the host plants }\end{array}$ & Dewinged, roasted or dry-fried & $\begin{array}{l}\text { Dry-fried during the } \\
\text { swarming season }\end{array}$ \\
\hline Kigelegele & $\begin{array}{l}\text { Hand picking after signs of their presence } \\
\text { are detected. }\end{array}$ & $\begin{array}{l}\text { Any time during the day preferably } \\
\text { morning and evening hours }\end{array}$ & Boiled and Fried & Drying \\
\hline Kansenda & $\begin{array}{l}\text { Hand picking after signs of their presence } \\
\text { are detected. }\end{array}$ & $\begin{array}{l}\text { Any time during the day preferably } \\
\text { morning and evening hours }\end{array}$ & Fried & Drying \\
\hline Bangwangwa & $\begin{array}{l}\text { Hand picking after signs of their presence } \\
\text { are detected. }\end{array}$ & $\begin{array}{l}\text { Any time during the day preferably } \\
\text { morning and evening hours }\end{array}$ & Boiled and roasted & Drying \\
\hline Maguina & $\begin{array}{l}\text { Hand picking after signs of their presence } \\
\text { are detected. }\end{array}$ & $\begin{array}{l}\text { Any time during the day preferably } \\
\text { morning and evening hours }\end{array}$ & $\begin{array}{l}\text { Boiled, fried or roasted, } \\
\text { sometimes prepared in stews }\end{array}$ & Drying \\
\hline Mingungu & $\begin{array}{l}\text { Hand picking after signs of their presence } \\
\text { are detected. }\end{array}$ & $\begin{array}{l}\text { Any time during the day preferably } \\
\text { morning and evening hours }\end{array}$ & Boiled and roasted & Drying \\
\hline Ngohangoha & $\begin{array}{l}\text { Hand picking after signs of their presence } \\
\text { are detected. }\end{array}$ & $\begin{array}{l}\text { Any time during the day preferably } \\
\text { morning and evening hours }\end{array}$ & $\begin{array}{l}\text { Boiled, fried or roasted, } \\
\text { sometimes prepared in stews }\end{array}$ & Drying \\
\hline Bikolongo & $\begin{array}{l}\text { Hand picking after signs of their presence } \\
\text { are detected. }\end{array}$ & $\begin{array}{l}\text { Any time during the day preferably } \\
\text { morning and evening hours }\end{array}$ & Boiled and roasted & Drying \\
\hline Bachache & $\begin{array}{l}\text { Hand picking after signs of their presence } \\
\text { are detected. }\end{array}$ & $\begin{array}{l}\text { Any time during the day preferably } \\
\text { morning and evening hours }\end{array}$ & $\begin{array}{l}\text { Boiled, fried or roasted, } \\
\text { sometimes prepared in stews }\end{array}$ & Drying \\
\hline
\end{tabular}


528

529

530

531

532

533

534

535

536

537

538

539

540

541

542

543

544

545

546

547

548

549

550

551

552

553

554

555

556

557

558

559

560

These results are consistent with those of Meutchieye et al. (2016) and Ebenebe et al. (2017), who also pointed out that hand picking is one of the major techniques used to harvest crickets, Rhinocerus beetle, stinking grasshopper (in the early hours of the morning), African palm weevil (from rotting palm tree) and caterpillars, while light trapping is used to harvest termites, green grasshoppers, house cricket and mole cricket. In addition, Ebenebe et al. (2017) added that crickets were also harvested by digging out from the tunnels during the dry season, and that house cricket were also harvested by digging out from small sound mounds with depression that indicates their entrance. In contrast to the results of this study, Ebenebe et al. (2017) stated that mole crickets were harvested by light trapping. Singing a "Wee wee" song at the base of the host tree is another notable technique used to harvest the caterpillar of a particular moth species. The more you sing, the more they fall from the top of the tree and are harvested.

To harvest enough $R$. differens by light trapping during the swarming season, locals lit the lamps/bulbs outside the houses and secure the areas where these lamps/bulbs are located with corrugated iron sheets bent into a cone shape leading to baskets, small drums where the falling $R$. differens are harvested (Mmari et al., 2017). For non-swarming $R$. Differens, harvesting is done early in the morning between 6 and 7 AM, when they are inactive and not able to fly (Kinyuru et al., 2011). Additionally, Dao et al. (2020) reported two harvesting techniques including direct collection of termites from their mounds and trapping of termites in containers. Direct collection involves partially destroying termite mounds while trapping implies looking for signs of termite presence such as mud sheets and tracks on the ground. Techniques depend on the termite genus. Small termite mounds of Trinervitermes and Cubitermes can be dug with a hoe or pickaxe, and the mounds are collected in the morning between 6 and 9 AM. In trapping technique, the traps are placed in the morning 6 and $8 \mathrm{AM}$ or in the evening around $6 \mathrm{PM}$ and covered with foliage or pieces of cloth to protect it from the sun. The same harvesting techniques were recently described in Ghana by Boafo et al. (2019).

Ayieko et al. (2010) and Chung (2010) reported that edible insects were sun-dried, baked, steamed and processed into crackers, muffins and sausage meat. Our findings confirm those of Ebenebe et al. (2017) who also found that salted roasting is one of the techniques used to process termites, crickets, Rhinocerus beetle, grasshopper and locust. They added that grasshopper and locust are consumed dried as well. On the other hand, African palm weevil are consumed raw or fried with pepper sauce. This study found that drying was the most used preservation technique as it's the most widely used technology for increasing the shelf-life of 
561 foods. It ranges from traditional methods such as roasting, frying and solar drying to modern

562 methods such as freeze-drying and microwave assisted drying (Melgar-lalanne et al., 2019).

\section{4. Conclusion and recommendations}

564 The wide biodiversity of edible insects observed clearly depicts the importance of 565 entomophagy in the region. Twenty-three edible insects were recorded belonging to nine

566 families and five orders. These insects are consumed as larvae, adults or as eggs and pupa.

567 About four of them were the most popular edible insects in Fizi and Mwenga, two in Kabare, 568 and six in Walungu Territory. Additionnally, $R$. differens, I. oyemensis, A. melifera larvae, $G$. 569 africana and Nsike were the most preferred for their taste. Besides, some are available 570 throughout the year, while the others are less available. A large number of plants have been 571 recorded as host plants, including even plants used as source of food, feed and income for 572 humans. Like harvesting strategies and time, processing methods and preservation techniques 573 vary according to local knowledge and practices, as well as to the insect species. These results suggest similar studies across the country and further research on the nutritional and safety profiling of processed and non-processed edible insects, while encouraging the rearing of certain edible insects for mass production as the demand is too high.

\section{Acknowledgements}

578 The authors would like to thank Benjamin Kalalizi, Belanila Victoire, Rebecca Kajuru, Sandra 579 Lukausa and Tresor Buhendwa for their contribution to data collection. We also extend our 580 acknowledgements to the Université Evangélique en Afrique (UEA) and the Regional 581 Universities Forum for Capacity Building in Agriculture (RUFORUM) for their support (Grant ID: Grant\#RU/2020/GTA/DRG/015).

\section{Author contributions}

Conceptualization; J. I. and R. A. Methodology; J. I., R. A., J. K., K. K., D. B., S. N. and P. U. Validation; All authors; Data collection; J.I. Data curation; J. I and R. A. Formal analysis \& 


\section{References}

Ayieko, M., Oriaro, V., \& Nyambuga, I. (2010). Processed products of termites and lake flies: improving entomophagy for food security within the Lake Victoria region. African Journal of Food, Agriculture, Nutrition and Development, 10(2), 2085-2098.

Boafo, H. A., Affedzie-obresi, S., Dossou, S., Gbemavo, C., Clottey, V. A., Nkegbe, E., ... Kenis, M. (2019). Use of Termites by Farmers as Poultry Feed in Ghana. Insects, 1-13. https://doi.org/10.3390/insects10030069

Bomolo, O., Niassy, S., Chocha, A., Longanza, B., Bugeme, D. M., Ekesi, S., \& Tanga, C. M. (2017). Ecological diversity of edible insects and their potential contribution to household food security in Haut-Katanga Province, Democratic Republic of Congo. African Journal of Ecology, 640-653. https://doi.org/10.1111/aje.12400

CAID (2021). Fiches d'administration des Territoires. Cellule d'Analyses des Indicateurs de Développement (CAID). Gombe, Kinshasa, RD Congo.

Chakravorty, J., Ghosh, S., \& Mesyer-rochow, V. B. (2013). Comparative Survey of Entomophagy and Entomotherapeutic Practices in Six Tribes of Eastern Arunachal Pradesh ( India ). Journal of Ethnobiology and Ethnomedicine, 1-12.

Chung. (2010). Edible insects and entomophagy in Borneo. Retrieved from $\mathrm{http} / / /$ buglady.dk/wp-content/uploads/2015/02/edible-forest-inescts.pdf\#page $=182$

Cicatiello, C., Rosa, B. De, Franco, S., \& Lacetera, N. (2016). Consumer approach to insects as food: barriers and potential for consumption in Italy. British Food Journal, 118(9), 2271-2286. https://doi.org/10.1108/BFJ-01-2016-0015

Dao, A. N. C., Sankara, F., Pousga, S., Coulibaly, K., Nacoulma, J. P., Ouedraogo, S., ... Somda, I. (2020). Traditional methods of harvesting termites used as poultry feed in Burkina Faso. International Journal of Tropical Insect Science, 109-118.

Deroy, O., Reade, B., \& Spence, C. (2015). The insectivore's dilemma, and how to take the West out of it. Food Quality and Preference, 44, 44-55. https://doi.org/10.1016/j.foodqual.2015.02.007

Doocy, S., Emerson, J., Colantouni, E., Strong, J., Mansen, K. A., Ii, J., ... Nzanzu, J. (2018). Improving household food security in eastern Democratic Republic of the Congo: a comparative analysis of four interventions. Food Security, 649-660.

Ebenebe, C. I., Amobi, M. I., Udegbala, C., Ufele, A. N., \& Nweze, B. O. (2017). Survey of edible insect consumption in south-eastern Nigeria. Journal of Insects as Food and Feed, 3(4), 241-251. https://doi.org/10.3920/JIFF2017.0002 
632

633

634

635

636

637

638

639

640

641

642

643

644

645

646

647

648

649

650

651

652

653

654

655

656

657

658

659

660

661

662

663

664

665

Gahukar, R. T. (2011). Entomophagy and human food security. International Journal of Tropical Insect Science, 31(3), 129-144. https://doi.org/10.1017/S1742758411000257

Godfray, J. F., Pretty, J., Robinson, S., Thomas, S. M., \& Toulmin, C. (2010). Food Security : The Challenge of Feeding 9 billion People. Science, 327(February), 812-819.

Halloran, A., Vantomme, P., Hanboonsong, Y., \& Ekesi, S. (2015). Regulating edible insects : the challenge of addressing food security, nature conservation, and the erosion of traditional food culture. Food Security. https://doi.org/10.1007/s12571-015-0463-8

Hanboonsong, Y., Jamjanya, T., \& Durst, P. B. (2013). Six-legged livestock: edible insect farming, collec $\theta$ on and marke $\theta$ ng in Thailand.

Hartmann, C., Shi, J., Giusto, A., \& Siegrist, M. (2015). The psychology of eating insects : A cross-cultural comparison between Germany and China. FOOD QUALITY AND PREFERENCE, 44, 148-156. https://doi.org/10.1016/j.foodqual.2015.04.013

Hoare, A. (2007). THE USE OF NON-TIMBER FOREST PRODUCTS IN THE CONGO BASIN : Constraints and Opportunities.

Kelemu, S., Niassy, S., Torto, B., Fiaboe, K., Affognon, H., Tonnang, H., ... Ekesi, S. (2015). African edible insects for food and feed: inventory, diversity, commonalities and contribution to food security. Journal of Insects as Food and Feed, 1(2), 103-119. https://doi.org/10.3920/JIFF2014.0016

Kim, R., Martin, B., Nielsen, R., \& Thorsen, B. J. (2017). Household determinants of bushmeat and eru (Gnetum africanum ) harvesting for cash in the Democratic Republic of Congo. Environment, Development and Sustainability, 19(4), 1425-1443. https://doi.org/10.1007/s10668-016-9812-9

Kinyuru, J. N, Kenji., G. M., Muhoho, S. N., \& Ayieko, M. (2010). Nutritional potential of longhorn grasshopper (ruspoliadifferens) consumed in Siaya district, Kenya. Journal of Agriculture, Science and Technology, 32-46.

Kinyuru, John N, Konyole, S. O., Roos, N., Onyango, C. A., Owino, V. O., Owuor, B. O., ... Kenji, G. M. (2013). Nutrient composition of four species of winged termites consumed in western Kenya. Journal of Food Composition and Analysis, 30(2), 120-124. https://doi.org/10.1016/j.jfca.2013.02.008

Kinyuru, John N, Mogendi, J. B., Riwa, C. A., \& Ndung, N. W. (2015). Edible insects - a novel source of essential nutrients for human diet : Learning from traditional knowledge. Animal Frontiers, 14-19. https://doi.org/10.2527/af.2015-0014

Kinyuru, John N, Nyangena, D., Kamau, E., Ndiritu, A., Muniu, J., Kipkoech, C., ... Mmari, M. (2018). The Role of Edible Insects in Diets and Nutrition in East Africa. In In: 
666

667

668

669

670

671

672

673

674

675

676

677

678

679

680

681

682

683

684

685

686

687

688

689

690

691

692

693

694

695

696

697

698

699

Halloran A., Flore R., Vantomme P., Roos N. (eds) Edible Insects in Sustainable Food Systems. Springer, Cham. (pp. 93-108). https://doi.org/10.1007/978-3-319-74011-9

Kou, L., \& Adámková, A. (2016). Nutritional and sensory quality of edible insects. NFS Journal, 4, 22-26. https://doi.org/10.1016/j.nfs.2016.07.001

Kulma, M., Kou, L., Homolková, D., \& Plachý, V. (2020). Effect of developmental stage on the nutritional value of edible insects . A case study with Blaberus craniifer and Zophobas morio. Journal of Food Composition and Analysis, 92(October 2019). https://doi.org/10.1016/j.jfca.2020.103570

Laureati, M., Proserpio, C., Jucker, C., \& Savoldelli, S. (2016). NEW SUSTAINABLE PROTEIN SOURCES : CONSUMERS' WILLINGNESS TO ADOPT INSECTS. Italian Journal of Food Science, (January).

Lensvelt, E. J. S., \& Steenbekkers, L. P. A. (2014). Exploring Consumer Acceptance of Entomophagy: A Survey and Experiment in Australia and the Netherlands. Ecology of Food and Nutrition, 53(5), 543-561. https://doi.org/10.1080/03670244.2013.879865

Levang, P., Lescuyer, G., Noumbissi, D., \& Déhu, C. (2015). Does gathering really pay ? Case studies from forest areas of the East and South regions of Cameroon. Forests, Trees and Livelihoods, 8028. https://doi.org/10.1080/14728028.2014.1000980

Looy, H., \& Wood, J. R. (2006). Attitudes Toward Invertebrates: Are Educational "Bug Banquets" Effective? The Journal of Environmental Education ISSN:, 8964. https://doi.org/10.3200/JOEE.37.2.37-48

Malaisse, F., \& Latham, P. (2014). Human consumption of Lepidoptera in Africa : an updated chronological list of references ( 370 quoted!) with their ethnozoological analysis. GeoEco-Trop: Revue Internationale de Géologie, de Géographie et d'Écologie Tropicales, 339-372.

Malinga, G. M., Valtonen, A., Lehtovaara, V. J., Rutaro, K., Opoke, R., \& Nyeko, P. (2018). Mixed artificial diets enhance the developmental and reproductive performance of the edible grasshopper, Ruspolia differens ( Orthoptera : Tettigoniidae ). Applied Entomology and Zoology, 53(2), 237-242. https://doi.org/10.1007/s13355-018-0548-x

Melgar-lalanne, G., Hernandez-Alvarez, A.-J., \& Salinas-Castro, A. (2019). Edible Insects Processing: Traditional and Innovative Technologies. Comprehensive Reviews in Food Science and Food Safety, 18. https://doi.org/10.1111/1541-4337.12463

Meutchieye, F., Tsafo, K. E. ., \& Niassy, S. (2016). Inventory of edible insects and their harvesting methods in the Cameroon centre region. Journal of Insects as Food and Feed, 2(3), 145-152. https://doi.org/10.3920/JIFF2015.0082 
700

701

702

703

704

705

706

707

708

709

710

711

712

713

714

715

716

717

718

719

720

721

722

723

724

725

726

727

728

729

730

731

732

733

Meyer-rochow, V. B. (2009). Food taboos : their origins and purposes. Journal of Ethnobiology and Ethnomedicine, 10, 1-10. https://doi.org/10.1186/1746-4269-5-18

Mishyna, M., \& Chen, J. (2020). Sensory attributes of edible insects and insect-based foods Future outlooks for enhancing consumer appeal. Trends in Food Science \& Technology, 95(April 2019), 141-148. https://doi.org/10.1016/j.tifs.2019.11.016

Mmari, M. W., Kinyuru, J. N., Laswai, H. S., \& Okoth, J. K. (2017). Traditions , beliefs and indigenous technologies in connection with the edible longhorn grasshopper Ruspolia differens ( Serville 1838 ) in Tanzania. Journal of Ethnobiology and Ethnomedicine, 111. https://doi.org/10.1186/s13002-017-0191-6

Musundire, R., Zvidzai, C. J., \& Chidewe, C. (2014). Bio-Active Compounds Composition in Edible Stinkbugs Consumed in South- Bio-Active Compounds Composition in Edible Stinkbugs Consumed in South-Eastern Territories of Zimbabwe. International Journal of Biology, (Ii). https://doi.org/10.5539/ijb.v6n3p36

Ngute, A. S. K., Dongmo, M. A. K., Effa, J. A. M., Onguene, E. M. A., Lontchi, J. F., Cuni-, A., ... Cuni-sanchez, A. (2020). Edible caterpillars in central Cameroon: host plants , value, harvesting, and availability. Forests, Trees and Livelihoods, 29(1), 16-33. https://doi.org/10.1080/14728028.2019.1678526

Obopile, M., \& Seeletso, T. G. (2013). Eat or not eat : an analysis of the status of entomophagy in Botswana. Food Security, 817-824. https://doi.org/10.1007/s12571-013-0310-8

Opoke, R., Nyeko, P., Malinga, G. M., Rutaro, K., Roininen, H., \& Valtonen, A. (2019). Host plants of the non - swarming edible bush cricket Ruspolia differens. Ecology and Evolution, (December 2018), 1-10. https://doi.org/10.1002/ece3.5016

Payne, C L R, Scarborough, P., Rayner, M., \& Nonaka, K. (2015). Are edible insects more or less 'healthy' than commonly consumed meats? A comparison using two nutrient profiling models developed to combat over- and undernutrition. European Journal of Clinical Nutrition, 70(May), 1-7. https://doi.org/10.1038/ejcn.2015.149

Payne, Charlotte L R. (2016). Entomophagy in the area surrounding LuiKotale, Salonga National Park, Democratic Republic of the Congo. African Study Monographs.

Premalatha, M., Abbasi, T., Abbasi, T., \& Abbasi, S. A. (2011). Energy-efficient food production to reduce global warming and ecodegradation: The use of edible insects. Renewable and Sustainable Energy Reviews, 15(9), 4357-4360. https://doi.org/10.1016/j.rser.2011.07.115

Raheem, D., Carrascosa, C., Oluwole, O. B., Saraiva, A., Millán, R., \& Raposo, A. (2018). Traditional consumption of and rearing edible insects in Africa, Asia and Europe. Critical 
8398.

Raheem, D., Carrascosa, C., Oluwole, O. B., Saraiva, A., Millán, R., \& Raposo, A. (2019). Traditional consumption of and rearing edible insects in Africa, Asia and Europe. Critical Reviews in Food Science and Nutrition, 8398. https://doi.org/10.1080/10408398.2018.1440191

Ramos-elorduy, J. (2006). Threatened edible insects in Hidalgo, Mexico and some measures to preserve them. Journal of Ethnobiology and Ethnomedicine, 10, 1-10. https://doi.org/10.1186/1746-4269-2-51

Raubenheimer, D., \& Rothman, J. M. (2013). Nutritional Ecology of Entomophagy in Humans and Other Primates. Annual Review of Entomology, (September 2012), 141-160. https://doi.org/10.1146/annurev-ento-120710-100713

Riggi, L. G., Veronesi, M., \& Goergen, G. (2016). Observations of entomophagy across Benin - practices and potentials. Food Security, 139-149. https://doi.org/10.1007/s12571-0150509-y

Rumpold, B. A., \& Schlüter, O. K. (2013). Potential and challenges of insects as an innovative source for food and feed production. Innovative Food Science and Emerging Technologies, 17, 1-11. https://doi.org/10.1016/j.ifset.2012.11.005

Sánchez-Muros, M. J., Barroso, F. G., \& Manzano-Agugliaro, F. (2014). Insect meal as renewable source of food for animal feeding: A review. Journal of Cleaner Production, 65, 16-27. https://doi.org/10.1016/j.jclepro.2013.11.068

Schabel, H. (2006). Forest-based insect industries. In Forest entomology in East Africa: forest insects of Tanzania.

Schlup, Y., \& Brunner, T. (2018). Prospects for insects as food in Switzerland: A tobit regression. Food Quality and Preference, (October). https://doi.org/10.1016/j.foodqual.2017.10.010

Smith, A. B. T., \& Paucar, A. (2000). Taxonomic Review of Platycoelia lutescens ( Scarabaeidae : Rutelinae : Anoplognathini ) and a Description of its Use as Food by the People of the Ecuadorian Highlands. Annals of the Entomological Society of America, 408-414.

Twine, W., Moshe, D., Netshiluvhi, T., \& Siphugu, V. (2003). Consumption and direct-use values of savanna bio-resources used by rural households in Mametja , a semi-arid area of Limpopo province, South Africa. South African Journal of Science, (October), 467473. 
United Nations. (2019). Publications World Population Prospects 2019 : Highlights, 1-5.

Valtonen, A., Malinga, G. M., Junes, P., Opoke, R., Lehtovaara, V. J., Nyeko, P., \& Roininen, H. (2018). The edible katydid Ruspolia differens is a selective feeder on the in $\mathrm{fl}$ orescences and leaves of grass species. Entomologia Experimentalis et Applicata, 592602. https://doi.org/10.1111/eea.12707

Van Huis, A. (2013). Potential of Insects as Food and Feed in Assuring Food Security. Annual Review of Entomology. https://doi.org/10.1146/annurev-ento-120811-153704

Van Huis, A. and O., \& Oonincx, D. G. A. B. (2017). The environmental sustainability of insects as food and feed. A review. Agronomy for Sustainable Development. https://doi.org/10.1007/s13593-017-0452-8

Vliet, N. Van, Muhindo, J., Nyumu, J. K., \& Nasi, R. (2019). From the Forest to the Dish : A Comprehensive Study of the Wildmeat Value Chain in Yangambi, Democratic Republic of Congo. Frontiers in Ecology and Evolution, 7(April). https://doi.org/10.3389/fevo.2019.00132

Wilkinson, K., Muhlhausler, B., Motley, C., Crump, A., Bray, H., \& Ankeny, R. (2018). Australian Consumers' Awareness and Acceptance of Insects as Food. Insects, 1-11. https://doi.org/10.3390/insects9020044

Woolf, E., Zhu, Y., Emory, K., Zhao, J., \& Liu, C. (2019). Willingness to consume insectcontaining foods : A survey in the United States. LWT - Food Science and Technology, 102(September 2018), 100-105. https://doi.org/10.1016/j.lwt.2018.12.010 